\title{
Estimation of the Predictive Powers of Teachers' Pedagogical Skills on Pupils'Academic Achievement in Christian Religious Studies in South-East, Nigeria
}

\author{
Victor Sunday Ezema ${ }^{1}$, Juliana N. Ejiofor ${ }^{1}$, Joy Chioma Orji ${ }^{2}$, Emmanuel Chidobe Okenyi ${ }^{1}$, Wilfred Iorfa Achagh ${ }^{3}$, \\ Julie U. Ibiam ${ }^{1}$, Christian Sunday Ugwuanyi ${ }^{4}$, Leonard C. Illechukwu ${ }^{5} \&$ Ekwutosi Monica Nnadi ${ }^{5}$ \\ ${ }^{1}$ Department of Educational Foundations (Childhood Education), University of Nigeria, Nsukka, Nigeria \\ ${ }^{2}$ Institute of Education, University of Abuja, Nigeria \\ ${ }^{3}$ Department of Early Childhood Care and Education, FCT College of Education, Zuba Abuja, Nigeria \\ ${ }^{4}$ Department of Science Education, University of Nigeria, Nsukka, Nigeria \\ ${ }^{5}$ Department of Arts Education, University of Nigeria, Nsukka, Nigeria \\ Correspondence: Christian S. Ugwuanyi, Department of Science Education, University of Nigeria, Nsukka, \\ Nigeria. E-mail: christian.ugwuanyi@unn.edu.ng
}

Received: September 18, 2019 Accepted: October 31, 2019 Online Published: November 10, 2019

doi:10.5539/gjhs.v11n14p30 URL: https://doi.org/10.5539/gjhs.v11n14p30

\begin{abstract}
The general purpose of this study was to determine teachers' pedagogical skills as predictors of pupils' academic achievement in Christian Religious Studies in South East, Nigeria. The study adopted a correlation research design. Two questions were posed and two hypotheses were formulated and tested for the study. The study was carried out in all the primary schools in South-East, Nigeria. The population of the study included all the 42,796 primary school teachers in South-East, Nigeria. A sample of 855 public primary school teachers was drawn for the study using a multi-stage random sampling procedure. Two instruments were used for data collection, they are: Teachers' Pedagogical Skills Questionnaire (TPSQ) and Pupils' Academic Achievement Proforma (PAAP). The instruments were validated by three experts. The reliability of the instrument was established by trial-testing on 20 primary school teachers that were randomly drawn from Ezinihite-Mbaise Local Government Area of Imo State which is a part of the study area but not a sampled area. Cronbach's Alpha Reliability Coefficient was used to determine the internal consistency reliability index 0.89 for TPSQ. Data collected were analyzed using Correlation Coefficient and Regression Analysis of Variance was used to test the hypotheses at 0.05 level of significance. The findings revealed that teachers' pedagogical skills significantly predicted pupils' academic achievement in Christian Religious Studies in South-East. It was recommended that teachers should possess sufficient knowledge and skills regarding curriculum content and classroom management in order to overcome classroom challenges.
\end{abstract}

Keywords: teachers' pedagogical skills, pupils achievement, christian religious studies

\section{Introduction}

Pupils' academic achievement in school subjects especially Christian Religious Studies (CRS) has been the major concern of childhood educators and researchers. Christian Religious Studies is one of the subjects taught in primary schools as bequeathed to the Nigerian educational system by the missionaries. The National Christian Religious Studies Curriculum (FRN, 2004) which is an official document of the Federal Government of Nigeria states that the aim is to produce citizens who have attained all-round personal development; educationally, morally, socially and spiritually. According to Onovughe and Mordi (2017), the goal of Christian Religious Studies among others is to develop pupils' character and moral training that enables pupils a sound attitude.

Despite the lofty and noble benefits of Christian Religious Studies, there have been reports of the persistent poor performance of pupils in Christian Religious Studies in Nigeria, with particular reference to South-East. A cursory look at pupils' termly academic results in Christian Religious Studies is demoralizing. More disturbing is the data analysis of pupils' academic achievement on First School Leaving Certificate examinations over the years with particular reference to Christian Religious Studies, which is an aspect of General Paper taken in the examinations. Precisely, the analysis from 2011 to 2017 shows a downward trend (Enugu State Universal Basic Education Board, 
2018). This report is a confirmation of the earlier observation by Lawal (2002) that pupils' performance in the subject is diminishing and poor to the extent that given the opportunity, many pupils will run away from the subject in external examinations.

This alarming rate of poor performance in Christian Religious Studies has generated growing concern from various quarters, parents, teachers, schools and the government. Baamphatha, Koketso, BoitumeloMasego, Rebonyetsala, Bafedile, Mpolokang, and Oshi (2016) attribute the poor performance mainly to teachers' lack of assessment skills in handling the subject. Meanwhile, in many primary schools in South-East, Nigeria, one easily finds teachers who lack pedagogical skills. According to Barber and Mourshed (2007), available evidence suggests that the main driver of the variation in children's learning at school is the quality of the teachers. In a similar development, Fakeye (2012) believes that the quality of teachers has a larger impact on the learning of pupils than the quality of the curriculum, the teaching methods, the school building or the role of parents. Teachers are among the important players that most likely influence pupils' achievement, depending on their pedagogical skills.

Pedagogical skills of teachers, according to Razzak and Akhtar (2014) refer to teachers' knowledge about the basic teaching and learning skills such as teaching approaches, curricular design, evaluation techniques and managerial issues. In the context of this study, pedagogical skills refer to classroom management skills and content-related skills of teachers. For AbdulRaheem and Amali (2013), teachers' pedagogical skills enable classroom teachers to have a good and thorough understanding of the subjects they teach. Such skills help to appreciate how the knowledge gained over time in various subject areas could be organized and linked to other areas of knowledge. No teacher can truly be effective without classroom management skills and content-related skills of teachers.

Content-related skills are aspects of teachers' pedagogical skills. According to Guerriero (2017), content-related skills of teachers refer to the body of knowledge, information and skills with which teachers teach and by which learners are expected to learn in a given subject or content area. Simply put, they generally refer to the abilities of teachers by which facts, concepts, theories and principles that are taught and learned in specific academic areas. In the context of this study, content-related skills refer to the specialized knowledge and abilities of teachers needed for effective teaching and learning to take place. They enable teachers to create a learning environment that is challenging, engaging and rich. These, in turn, enable pupils to meet their target learning outcomes as well as be interested and motivated. Such skills appear necessary for learning, which in turn affects the general climate of schools. According to Langsajo (2014), teachers' content knowledge is a leading factor in teaching and learning as it helps the teacher to efficiently impart knowledge. It is often argued that it has a direct bearing on pupils' understanding of subject matter and in their overall academic achievement. This is because if the teacher is largely ignorant, he or she can do much harm but when he or she has much knowledge, he or she is able to explain the lessons well and the likelihood of pupils to understand becomes very high. In other words, the extent to which a teacher and the pupils will achieve depends largely on the teachers' academic competency in the subject. Pedagogical content knowledge of teachers thus explained is often complemented by the teachers' classroom management skills.

Classroom management is another aspect of pedagogical skills needed by teachers for effective teaching and learning. According to Jones and Jones (2004), classroom management is an ongoing process requiring teachers to make decisions about various situations such as where and with whom the pupils should sit down; which teaching methods should be followed; how to ensure participation and motivation; which materials to use; and how to deal with misbehaviours. This is important as teaching and learning may not take place effectively in a mismanaged classroom. Teachers' efficacy in classroom management depends on their academic and pedagogical background as well as their classroom management skills and experiences. Kemal (2009) noted that generally, teachers without sufficient knowledge and skills regarding classroom management find no way out in the face of classroom challenges. Such teachers may tend to use their authority in a manner that adversely affects the overall climate of the school. In the Nigerian context, there is a dearth of empirical evidence of the predictive powers of teachers' pedagogical skills on pupils' achievement in CRS. Thus, the researchers sought answers to the following questions:

1) What is the predictive power of teachers' classroom management skills on pupils' academic achievement in Christian Religious Studies in South-East, Nigeria?

2) What is the predictive power of teachers' content-related skills on pupils' academic achievement in Christian Religious Studies?

The following null hypotheses were formulated and tested at $5 \%$ probability values.

$\mathbf{H o}_{1}$ : There is no significant predictive power of teachers' classroom management skills on pupils' academic 
achievement in Christian Religious Studies.

$\mathbf{H o}_{2}$ : There is no significant predictive power of teachers' content-related skills on pupils' academic achievement in Christian Religious Studies.

\section{Materials and Methods}

The study adopted a correlational survey research design. Correlational survey research design, according to Nworgu (2015), seeks to establish what relationship exists between two or more variables. Such studies indicate the magnitude of the relationship among variables.

The population of the study comprised 42,796 primary school teachers in South-East, Nigeria with a sample size 855 public primary school teachers. A multi-stage sampling procedure was adopted in drawing the samples. In the first stage, three states were drawn from the five states that make up South-East, Nigeria using simple random sampling technique. Specifically, the slip of paper method was used. The researchers wrote the names of states on slips of paper and folded them. The folded papers were put in a bag and reshuffled thoroughly. The researchers dipped hand and picked one slip without looking into the bag. The slip was unfolded and the name of the state in the slip was recorded. The process was repeated with replacement until the three states were drawn. In the second stage, 6 Local Government Areas were drawn from Anambra State, 4 from Ebonyi State and 5 from Enugu State using proportionate stratified random sampling technique, giving a total of 15 Local Government Areas for the study. In the third stage using the same proportionate stratified random sampling technique, 38 public primary schools were drawn from 6 different Local Government Areas in Anambra State. In Ebonyi State, 23 schools were drawn from four 4 different Local Government Areas. In Enugu State, 34 public primary schools were drawn from five 5 different Local Government Areas. In all, 95 public primary schools were drawn from fifteen 15 Local Government Areas. Finally, a simple random sampling technique was used to draw teachers from the sampled schools. The sample sizes for teachers drawn from Anambra, Ebonyi and Enugu States are 325, 333 and 197 respectively making a total sample size of 855 public primary school teachers. Nine (9) teachers were drawn from each of the 95 sampled public primary schools.

\subsection{Measures}

A questionnaire titled Teachers' Pedagogical Skills Questionnaire (TPSQ) and Pupils' Academic Achievement Proforma (PAAP) were used to collect the relevant data for this study. Section A of the instrument elicited information on the demographic characteristics of the respondents while section B elicited information on teachers' pedagogical skills made up of eighteen items and organized in two clusters. Cluster A was on classroom management skills while cluster B was on content-related skills adapted from the Organization for Economic Cooperation and Development's Teaching and Learning International Survey, (2013).Each of the clusters has a four-point rating scale with the following response options: Strongly Agree (SA) $=4$, Agree (A) $=3$, Disagree (D) $=2$ and Strongly Disagree $(\mathrm{SD})=1$.

Pupils' academic achievement Pro-forma was used to collect achievement scores of the pupils in Christian Religious Studies for three terms. The average score of the pupils for the three terms (first, second and third terms' results) was thus determined. The average scores of pupils in Christian Religious Studies were correlated with their scores from the instruments that addressed other variables.

The instruments were face-validated by three experts in the content areas and area of measurement and evaluation. The experts were requested to go through the instruments and ascertain their appropriateness for the study bearing in mind the purposes of the study, research questions and hypotheses. The reliability of the instrument was established by trial-testing the instruments on 20 primary school teachers, who were randomly drawn from Ezinihitte-Mbaise Local Government Area in Imo State. Cronbach's Alpha Reliability method was used to determine the internal consistency of the items of the questionnaire to be 0.77 .

\subsection{Method of Data Analysis}

Data collected were analyzed using simple regression analysis. The research questions were answered using the coefficient of determination while the null hypotheses were tested at 0.05 level of significance using analysis of variance aspect of regression analysis. Based on the guideline of Dowine and Heath as cited in Nworgu (2015) for interpreting correlation coefficient result, 0.8 and above $=$ high; above 0.3 to $0.8=$ moderate; 0.3 and below $=$ low.

\section{Results}

\subsection{Research Question One}

What is the predictive power of teachers' classroom management skills on pupils' academic achievement in Christian Religious Studies in South-East, Nigeria? 
Table 1. Regression analysis of the predictive power of teachers' classroom management skills on pupils' academic achievement in christian religious studies

\begin{tabular}{llc}
\hline Variable & $\mathrm{r}$ & $\mathrm{R}^{2}$ \\
\hline Teachers' classroom management Skills & 0.66 & 0.44 \\
Pupils' academic achievement & & \\
\hline $\mathrm{r}^{2}=$ coefficient of determination. &
\end{tabular}

Table 1 shows that the correlation coefficient between teachers' classroom management skills and pupils' academic achievement in Christian Religious Studies was 0.66. This means that there is a positive relationship between teachers' classroom management skills and pupils' academic achievement in Christian Religious Studies. The coefficient of determination (the predictive value) associated with the correlation coefficient of 0.66 is 0.44 . This implies that teachers' classroom management skills have the power to predict up to $44 \%$ of pupils' academic achievement in CRS. This is also an indication that $56 \%$ of pupils' academic achievement in Christian Religious Studies is predicted by other factors rather than teachers' classroom management skills.

Ho $_{1}$ : Teachers' classroom management skills do not significantly predict pupils' academic achievement in Christian Religious Studies in South-East, Nigeria.

Table 2. Analysis ofvariance of the predictive power of teachers' classroom management skills on pupils' academic achievement

\begin{tabular}{llllllll}
\hline & Model & Sum of squares & df & Mean Square & F & Sig. & Dec. \\
\hline \multirow{3}{*}{1} & Regression & 62190.298 & 1 & 62190.298 & 662.980 & 0.000 & $\mathrm{~S}$ \\
& Residual & 77857.479 & 830 & 93.804 & & & \\
\hline
\end{tabular}

Table 2 shows there a significant predictive power of teachers' classroom management skills on pupils' academic achievement in Christian Religious Studies, F $(1,830)=662.980, \mathrm{p}=.000$. Thus, the null hypothesis which stated that teachers' classroom management skills do not significantly predict pupils' academic achievement in Christian Religious Studies in South-East, Nigeria was therefore rejected.

\subsection{Research Question Two}

What is the predictive power of teachers' content-related skills on pupils' academic achievement in Christian Religious Studies?

Table 3. Correlation analysis of the predictive power of teachers' content-related skills on pupils' academic achievement in christian religious studies

\begin{tabular}{lll}
\hline Variable & $\mathrm{r}$ & $\mathrm{R}^{2}$ \\
\hline Teachers' content-related skill & 0.61 & 0.37 \\
Pupils' academic achievement & & \\
\hline $\mathrm{R}^{2}=$ coefficient of determination. & &
\end{tabular}

Table 3shows that the correlation coefficient between teachers' content-related skills and pupils' academic achievement in Christian Religious Studies was 0.61. This means there is a moderate positive relationship between teachers' content-related skills and pupils' academic achievement in Christian Religious Studies. The coefficient of determination associated with the correlation coefficient of 0.61 is 0.37 . This implies that $37 \%$ variation of pupils' academic achievement in Christian Religious Studies predicted by teachers' content-related skills. This is an indication that $63 \%$ of pupils' academic achievement in Christian Religious Studies is predicted by other factors rather than teachers' content-related skills.

$\mathbf{H o}_{2}$ : Teachers' content-related skills do not significantly predict pupils' academic achievement in Christian 
Religious Studies in South-East, Nigeria.

Table 4. Analysis of Variance of the Predictive Power of Teachers' Content-related Skills on Pupils' Academic Achievement

\begin{tabular}{llllclll}
\hline & Model & Sum of Squares & Df & Mean square & F & Sig. & Dec. \\
\hline \multirow{3}{*}{1} & Regression & 52459.758 & 1 & 52459.758 & 497.118 & 0.00 & S \\
\cline { 3 - 4 } & Residual & 87588.020 & 830 & 105.528 & & & \\
& Total & 140047.778 & 831 & & & & \\
\hline
\end{tabular}

Table 4 shows there is a significant predictive power of teachers' content-related skills on pupils' academic achievement in Christian Religious Studies, $\mathrm{F}(1,830)=497.11, \mathrm{p}=.000$. Thus, the null hypothesis which stated that teachers' content-related skills do not significantly predict pupils' academic achievement in Christian Religious Studies in South-East, Nigeria is therefore rejected. This implies that teachers' content-related skills are significant predictors of pupils' academic achievement in CRS.

\section{Discussion of Results}

The findings of the study showed that there is a significant positive relationship between teachers' classroom management skills and pupils' academic achievement in Christian Religious Studies. This also implies that teachers' classroom management skills are significant predictors of pupils' academic achievement in CRS. Thus, the higher the classroom management skills of teachers, the higher the academic achievement of pupils in CRS would be. Buttressing these findings, Evertson and Weinstein (2006) state that the purpose of classroom management is to enhance pro-social behaviour and increase pupils' academic engagement. This finding is also in line with the position of Sieberer-Nagler (2016) that classroom management is intended to provide pupils with more opportunities to learn all of the things that a teacher does to organize learners, space, time, and materials so that learning can take place. This confirms Martella, Nelson, and Marchand-Martella (2003) insistence that having a classroom that is well organized can result in positive behaviour and interaction among teachers and pupils, which more than likely will decrease the occurrences of behaviour problems within the classroom.

These findings confirmed the fact that classroom management seeks to establish and sustain an orderly environment so that pupils can engage in meaningful academic learning and it also enhances pupils' social and moral growth. This implies that well organized classrooms facilitate effective and efficient classroom teaching and learning while poor classroom organization is a barrier to teaching and learning. In other words, teachers who do not have sufficient knowledge and skills regarding classroom management find no way out in the face of classroom challenges. In summary, when teachers possess the under-listed classroom management skills, the academic achievement of pupils will be greatly enhanced. These skills include determining sitting arrangements in classrooms, creating an atmosphere of mutual respect in classrooms, getting the pupils to believe they can do well in school work, making expectations of good behaviour clear to pupils, developing rules that guide their classrooms, involving pupils in developing classroom guidelines, using strict measures to address serious disruptive behaviours and allowing pupils to work in small groups.

The findings of the study showed that there is a significant positive relationship between teachers' content-related skills and pupils' academic achievement in Christian Religious Studies. Thus, an increase in teachers' content-related skills leads to a corresponding increase in pupils' academic achievement in Christian Religious Studies. In support of these findings, Ogbonnaya (2013) believes that for effective classroom management and academic excellence of pupils, there is nothing as important as teachers' knowledge of the content and mastery of the subject matter. This finding is also in agreement with Langsajo's (2014) view that teachers' knowledge of curriculum content is a leading factor in teaching and learning as it helps the teacher impart knowledge in an efficient manner. The author adds that philosophical arguments and common sense support the conviction that teachers' knowledge of the subject matter affects learners' knowledge of curriculum content.

Since content-related skills refer to the specialized knowledge and abilities of teachers needed for effective teaching and learning to take place, such skills appear necessary for learning which in turn impact on the general school climate. Content-related skills enable teachers to create a learning environment that is challenging, engaging and rich. Such skills help the teachers know their pupils, what their interests are, their personalities and their learning styles, thereby enhancing their academic achievement. This is because if the teacher is largely ignorant, he or she can do much harm but when he or she has much knowledge, he or she is able to explain the 
lessons well, and the likelihood of pupils to understand, becomes very high. The possible result is that the pupils become interested and motivated and they meet their target learning outcomes as well.

\section{Conclusion}

Based on the findings of the study, the researchers concluded that teachers' content-related skills and classroom management skills are prime determinants of pupils' achievement in Christian Religious Studies.

\section{Implications of the Results}

The findings of the study have several implications among which are;

- The findings of this study will help them adopt serious measures and take concrete steps in recruiting competent teaching staff, providing adequate facilities and enabling school climate as well as other needed services.

- Classroom management by well-equipped teachers, in turn, facilitates teaching and learning of CRS.

\section{Recommendations}

Based on the findings, the following recommendations were made:

1) Classrooms should be well organized through sitting arrangements and group work to provide pupils with more opportunities to learn all the lesson objectives.

2) Teachers should acquire sufficient content-related skills and regard content knowledge as a leading factor in teaching and learning.

\section{Competing Interests Statement}

The researchers declared no potential conflict of interest of any kind.

\section{References}

AbdulRaheem, Y., \&Amali, I. O. (2013). Teachers' pedagogical skills and use of instructional materials as a correlate of students 'performance in Social Studies (Department of Social Sciences Education, University of Ilorin).

Barber, M., \& Mourshed, M. (2007). How the world's best-performing schools come out on top. London: McKinsey.

Dinama, B., Jeremiah, K., Sihlupheki-Jorowe, B., Keakantse, M., Kemoabe, R., Kgaswe, B., ... \& Sebina, O. (2016). Students' Academic Performance in Religious Education: A Case of Selected Schools in Botswana. International Journal of Learning, Teaching and Educational Research, 15(12), 67-83.

Evertson, C. M., \& Weinstein, C. S. (2006).Classroom management as a field of inquiry. In C. M. Evertson, \& C. S. Weinstein (Eds.), Handbook of classroom management: Research, Practice, and Contemporary Issues, 3-16.

Fakeye, D. O. (2012). Teachers' qualification and subject mastery as predictors of achievement in English Language in Ibarapapa Division of Oyo State. Global Journal of Human Social Science, 12(3),1-8.

F. R. N. (2004). National Christian religious studies, JSS 1-3. Lagos: NERDC.

Guerriero, S. (ed.). (2017). Pedagogical knowledge and the changing nature of the teaching profession.Educational Research and Innovation. Paris: OECD publishers.https://doi.org/10.1787/9789264270695-en

Jones, V. F., \& Jones, L. S. (2004).Comprehensive classroom management, creating communities of support and solving problems (7th, ed.). USA: Allyn\& Bacon Company.

Kemal, K. (2009). The effect of classroom management skills of elementary school teachers on undesirable discipline behaviour of students. Procedia Social and Behavioural Sciences, 1, 1215-1225. https://doi.org/10.1016/j.sbspro.2009.01.218

Langsajo, M. J. (2014).Impact of subject matter knowledge of a teacher in teaching and learning process. Middle Eastern and African Journal of Educational Research, 7, 20 -29.

Lawal, B.O. (2002). Teaching religions in colleges and universities. Ibadan, Stirling Horden Publishers (Nig.) Ltd.

Martella, R. C., Nelson, J. R., \& Marchand-Martella, N. E. (2003). Managing disruptive behaviour in the schools. Boston, MA: Allyn\& Bacon.

Nworgu, B. G. (2015). Educational research: basic issues and methodology. Nsukka: University Trust publishers. 
Ogbonnaya, N. O. (ed.) (2013). Classroom organization and management: issues, principles and practices. Awka: Meks publishers.

Onovughe, S., \& Mordi, J. F. (2017). The challenges of teaching Christian Religious Education in Nigerian schools and the way forward in the 21st century: a position paper. International Journal of Education and Evaluation, 3(6), 66-74.

Razzak, N., \& Akhtar, S. (2014). Problems faced by private sector primary school teachers in the application of pedagogical skills. Journal of Education and Educational Development, 1(1), 20-25. https://doi.org/10.22555/joeed.v1i1.6

Sieberer-Nagler, K. (2016). Effective classroom-management andpositive teaching. English Language Teaching, $9(1), 163-172$. https://doi.org/10.5539/elt.v9n1p163

\section{Copyrights}

Copyright for this article is retained by the author(s), with first publication rights granted to the journal.

This is an open-access article distributed under the terms and conditions of the Creative Commons Attribution license (http://creativecommons.org/licenses/by/4.0/). 